\title{
Modeling primary and secondary fractionation effects and atmospheric transport of polychlorinated biphenyls through single-source emissions
}

\author{
Song Cui $\odot$ - Qiang Fu • Chongguo Tian - Zulin Zhang • Rupert Hough • \\ Zhenxing Shen $\cdot$ Jianmin Ma $\cdot$ Lihui An $\cdot$ Yi-Fan Li
}

Received: 13 September 2018/Accepted: 27 January 2019/Published online: 10 February 2019

(C) Springer Nature B.V. 2019

\begin{abstract}
The Chinese Gridded Industrial Pollutants Emission and Residue Model (ChnGIPERM) was used to investigate potential fractionation effects and atmospheric transport of polychlorinated biphenyls (PCBs) derived from single-source emissions in China. Modeling the indicative PCBs (CB28, CB101, CB153, and CB180) revealed spatiotemporal trends in atmospheric transport, gas/particle partitioning, and primary and secondary fractionation effects. These included the inference that the Westerlies and East Asian monsoons affect atmospheric transport patterns of PCBs by influencing the atmospheric transport time (ATT). In this study, dispersion pathways with long ATTs in winter tended to have short
\end{abstract}

\section{S. Cui · Q. Fu}

International Joint Research Center for Persistent Toxic Substances (IJRC-PTS), School of Water Conservancy and Civil Engineering, Northeast Agricultural University, Harbin 150030, Heilongjiang, China

S. Cui · Y.-F. Li ( $₫)$

IJRC-PTS, State Key Laboratory of Urban Water

Resource and Environment, Harbin Institute of

Technology, Harbin 150090, Heilongjiang, China

e-mail: ijrc_pts_hit06@yahoo.com

C. Tian

Yantai Institute of Coastal Zone Research, Chinese Academy of Sciences, Yantai 264003, Shandong, China

Z. Zhang $\cdot$ R. Hough

The James Hutton Institute, Craigiebuckler,

Aberdeen AB15 8QH, UK ones in summer and vice versa. The modeled partitioning of PCB congeners between gas and particles was mainly controlled by temperature, which can further influence the ATT. The potential for primary and secondary fractionation was explored by means of numerical simulations with single-source emissions. Within ChnGIPERM, these phenomena were mainly controlled by the temperature and soil organic carbon content. The secondary fractionation of PCBs is a slow process, with model results suggesting a timescale of several decades.

\footnotetext{
Z. Shen

Department of Environmental Sciences and Engineering, Xi' an Jiaotong University, Xi' an 710049, China

J. Ma

College of Urban and Environmental Sciences, Peking University, Beijing 100871, China

L. An

State Environmental Protection Key Laboratory of Estuarine and Coastal Research, Chinese Research Academy of Environmental Sciences, Beijing 100012, China
} 
Keywords Polychlorinated biphenyls $\cdot$ Singlesource emission - Atmospheric transport - Primary fractionation $\cdot$ Secondary fractionation

\section{Introduction}

Polychlorinated biphenyls (PCBs) are one of the "dirty dozen" (Stockholm Convention) or "legacy POPs" (persistent organic pollutants) due to their high toxicity, persistence, high bioaccumulation through the food chain, and propensity for long-range atmospheric transport (LRAT) (UNEP 2001). Once emitted, POPs can be globally dispersed through processes including LRAT and ocean currents and accumulate in environmental media such as soil, water, sediment, coast, and biota (Wania and Mackay 1993, 1996; Wania et al. 1999; Xing et al. 2005; Ren et al. 2007; Yadav et al. 2017; Kim et al. 2017; Pokhrel et al. 2018; Hanh et al. 2018). Since the 1930s, PCBs have been used in many commercial products. Due to their thermal stability, extraordinary dielectric properties, and oxidation resistance, PCBs were mostly applied in products such as transformers and capacitors (Bozlaker et al. 2008). However, PCBs have also been associated with a number of undesirable health outcomes leading to their production being banned by the Stockholm Convention in 2001 (Wu et al. 2011; Wang et al. 2017; Cappelletti et al. 2018; Coxon et al. 2018).

To describe the atmospheric transfer of DDT from continents to oceans, the term "global distillation" was coined by Goldberg (1975). Subsequently, after entering the environment, the redistribution process of a pollutant may be latitudinally fractionated, depending on the ambient temperature and volatility of the pollutant. This has been termed "global fractionation" (Wania and Mackay 1993). In the redistribution process, however, LRAT acts as a "carrier" and moves chemicals from warmer regions to colder regions. Coincidently, in many cases, the transfer of pollutants is from emission sources to more remote or pristine areas (Meijer et al. 2003; von Waldow et al. 2010). This movement is accompanied by dry and wet deposition and has been recognized as the most important pathway for PCBs and other POPs (Wania and Mackay 1996). At the same time, LRAT is a compelling problem in the study of environmental distribution and fate due to elevated concentrations of POPs in polar regions and the concomitant "fractionation effect" theory. This quandary has led to numerous research studies attempting to quantify the global or regional transport and fate of POPs using measured or modeled data (Lohmann et al. 2007). Analogous fractionation of $\mathrm{PCBs}$ has been reported in several studies. For example, "urban fractionation" of PCBs was reported by Harner et al. (2004) for a relatively short distance ( $\sim 75 \mathrm{~km})$ along an urban-rural transect in Toronto. While their study did not reference the urban fractionation effect, Motelay-Massei et al. (2004) observed a clear gradient of one or two orders of magnitude for PAHs and PCBs as they moved from industrial to remote sites in the Seine River basin in France. According to soil monitoring data across China, Ren et al. (2007) observed PCB fractionation in soil from an urban-rural transect in the city of Shanghai ( $200 \mathrm{~km})$. "Urban fractionation" is less associated with "grasshopping" and air-soil exchange and more the result of proximity to a source region (i.e., a primary deposition area) (Li et al. 2010). In addition, "longitudinal fractionation" was observed by Ren et al. (2007) in a rural Chinese region due to most PCB usage in the eastern region than the western region in China. The latitudinal fractionation effect was also reported by Meijer et al. (2002, 2003), and their measured data included both soil and air data from southern UK to northern Norway.

Since the primary and secondary fractionation effects were proposed by $\mathrm{Li}$ et al. (2010), many scientists have shown a strong interest in studying the environmental distribution and behavior of POPs. For instance, primary sources (emission) influenced the distribution and background concentrations of PCBs in soils in the UK and Norway between 1998 and 2008 (Schuster et al. 2011). A primary fractionation effect was observed in the Tianjin region of China, with levels of PCBs dependent on proximity to major emission sources ( $\mathrm{Li}$ et al. 2011). However, these phenomena are based on measured air or soil data, and only a few studies have modeled the fractionation effect (Sweetman et al. 2002; Gouin et al. 2004; Scheringer et al. 2004; von Waldow et al. 2010; Lammel and Stemmler 2012; Stemmler and Lammel 2012; Zhao et al. 2017) or mountainous cold condensation effects using the ClimoChem model (Wegmann et al. 2006). This limits our ability to evaluate PCB pollution in a strategic way, limits our ability to make 
predictions about important sinks for PCBs, and ultimately reduces our ability to use limited resources more effectively.

Multimedia environmental models are useful tools for estimating fractionation phenomena (Mackay 2001). These models are able to incorporate physicochemical properties of individual PCBs, the geochemical properties of the soil and meteorological conditions; all of which can affect the distribution characteristics and atmospheric transport of PCBs. For example, China has a westerly and monsoon climate in the east part of the country. Additionally, the relatively complicated fractionation phenomena are difficult to observe by monitoring methods because they are influenced by many factors (meteorological conditions and soil properties), and the results are limited by sampling costs, compound pollution from different emission sources, as well as human activities or bioturbation.

In this study, we use numerical simulations using the Chinese Gridded Industrial Pollutants Emission and Residue Model (ChnGIPERM) (Cui et al. 2017) to explore the environmental behavior of PCBs derived from single-source emissions. The major objectives of this study are (1) to assess the atmospheric transport of PCBs derived from single-source emissions; (2) to determine the major factors that can influence the gasparticle partitioning of different PCB congeners in different regions or receptor sites, and (3) to explore primary and secondary fractionation.

\section{Methodology}

Model description

ChnGIPERM is a gridded mass balance model using a gridded system with a $1 / 6^{\circ}$ latitude and $1 / 4^{\circ}$ longitude resolution. A detailed description of the model can be found in Cui et al. (2017 \& SI). Briefly, the main model platform includes both transfer and transport modules.

For the transfer module, a level IV fugacity method is applied within each grid cell in order to calculate and describe temporal changes to concentrations of industrial pollutants as well as intercompartmental transfer of the modeled chemicals within a multimedia system. The transfer module consists of six soil types (urban land, dry cropland, paddy field, forestry, grassland, and uncultured land) with four soil vertical layers (or horizons), as well as water, sediment, and air (comprised of an atmospheric boundary layer (ABL, 0-1000 m) and an atmospheric low troposphere (ALT, 1000-4000 m)) compartments.

The transport module describes the mass exchange of chemicals between grid cells, which is driven by atmospheric transport (wind direction and speed) and water currents (Cui et al. 2017 and SI). The ChnGIPERM domain covers all of China spanning from $17^{\circ}$ to $55^{\circ} \mathrm{N}$ and $70^{\circ}$ to $135^{\circ} \mathrm{E}$ with 228 latitudinal grids and 260 longitudinal grids (Fig. 1).

Model experimental design and physicochemical properties of PCBs

\section{Model experimental design}

To better investigate the spatial and temporal characteristics of POPs in the environment, ChnGIPERM was employed to model the environmental behavior and distribution of PCBs from single-source emissions. To our knowledge, this is the first study on the regional distribution characteristics of POPs from single-source emissions in China. The source site (corresponding grid cell S1 (190, 96), Fig. 1) is located in eastern central China (E $118^{\circ} 22^{\prime}-119^{\circ} 14^{\prime}$; $\mathrm{N} 31^{\circ} 14^{\prime}-32^{\circ} 37^{\prime}$ ). Annual ambient air temperature at the source site ranges between -13.1 and $39.7{ }^{\circ} \mathrm{C}$ with an annual average temperature and rainfall of $15.4{ }^{\circ} \mathrm{C}$ and $1106 \mathrm{~mm}$, respectively. Figure 1 shows all four receptors in the latitudinal direction, which are from $\sim 22.2^{\circ} \mathrm{N}(\mathrm{R} 1)$ to $\sim 46.4^{\circ} \mathrm{N}(\mathrm{R} 4)$; the four sites and corresponding grid cells are R1 (174, 37), R2 (180, $81), \mathrm{R} 3(214,149)$, and R4 $(227,173)$ from south to north.

In general, PCBs have 209 congeners, and CB28, CB 52, CB 101, CB 118, CB 138, CB 153, and CB 180 are called indicative $\mathrm{PCB}$ because their physicochemical properties have been characterized more thoroughly than those of other PCB congeners. These PCBs can represent different PCB homologues. Hence, we selected representative low molecular weight (LMW) and high molecular weight (HMW) PCB congeners for modeling, including CB28, CB101, CB153, and CB180.

Numerical simulations were successively performed using an assumed emission rate $\left(1 \mathrm{~kg} \mathrm{~d}^{-1}\right.$ from source S1) for a single year only (1965) and can 
Fig. 1 The model domain and source $(\mathrm{S} 1$, green circle), receptors ( $\mathrm{R} 1, \mathrm{R} 2$, $\mathrm{R} 3$, and R4, blue circle), and observation sites (F1, F2, and F3, deep red circle). Solid light blue lines were used to extract latitude transect data along the emission source to observation sites

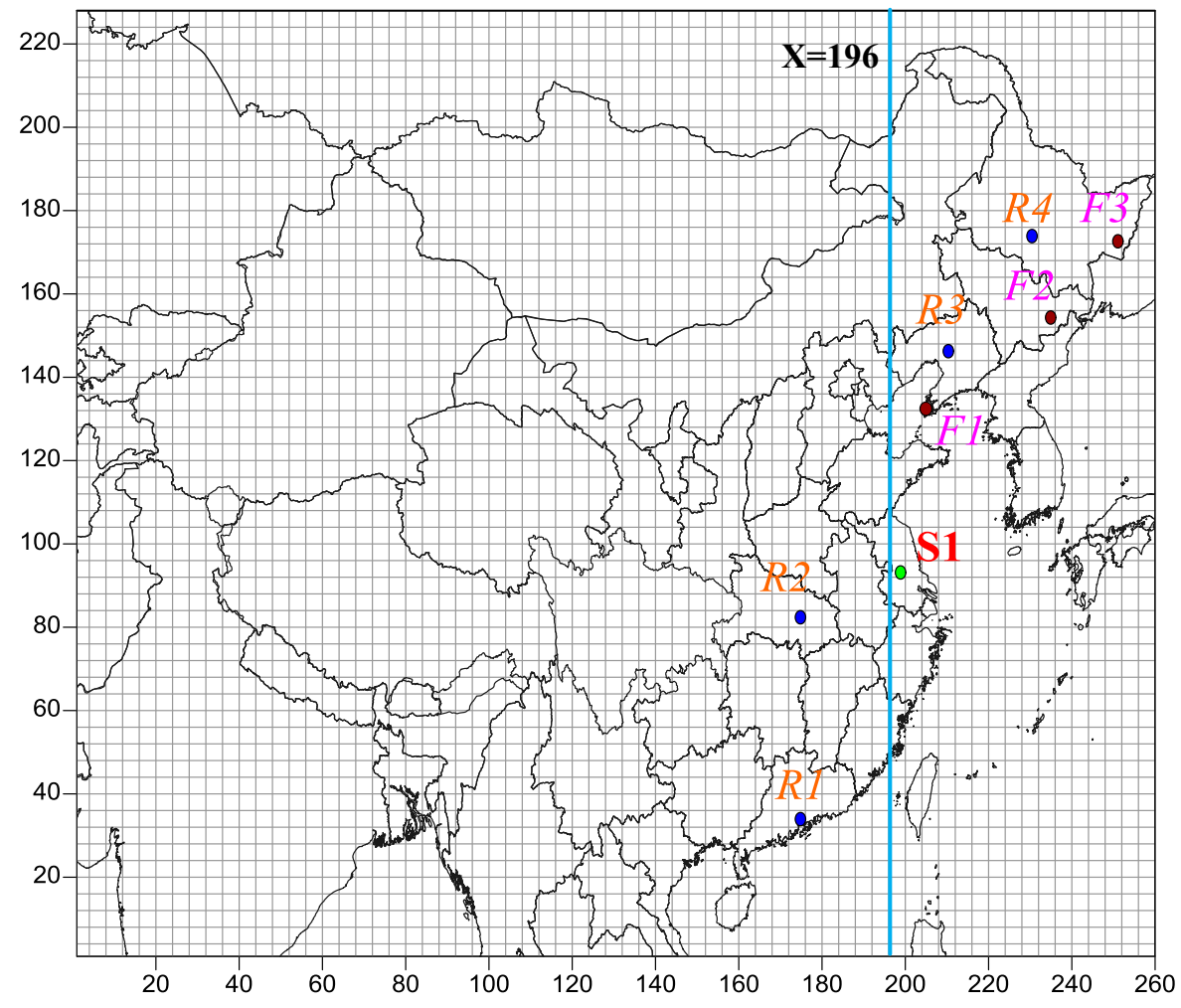

be thought of as a single emission event. Meteorological and environmental data ("Physicochemical properties of PCB congeners" section) from 1965 through 2010 were used to simulate potential for LRAT and fractionation phenomena. The spatial-temporal distribution of the single emission year (1965) was continually modeled until 2010 . The initial concentration of the selected PCB congeners in soil was assumed to be zero.

\section{Physicochemical properties of PCB congeners}

The model input data included gridded daily meteorological data (temperature, precipitation, wind direction and speed), soil parameters (density, organic carbon content, and porosity), surface features (urban, dry cropland, paddy field, grass, forest, uncultured land and water types), and physicochemical properties of the chemicals. Relevant physicochemical property data for the four representative congeners CB28, CB101, CB153, and CB180 are listed in Table 1.

\section{Results and discussion}

Atmospheric transport of PCBs

Many factors can affect the environmental distribution of POPs, such as meteorological conditions (temperature, wind direction and speed, precipitation, etc.) and environmental parameters (including soil type, soil organic carbon content, vegetation type). Atmospheric aerosols can also influence the presence of POPs in the atmosphere through deposition (dry and wet deposition) of absorbed POPs, which can influence the atmospheric transport of POPs from sources to remote regions.

In a previous study, the characteristic travel distance (CTD) was used to assess the transport potential of chemicals (Bennett et al. 1998). The CTD is the distance from the source region at which the concentration in the Lagrangian cell is reduced to 1/e of its initial value, i.e., by 63\% (Bennett et al. 1998). The concept of stickiness was introduced by Beyer et al. (2000) and indicates the fraction of a substance that will partition into and remain in a nonmobile medium, usually soil, and thus retard transport. In this 
Table 1 The physicochemical properties of the four PCB congeners used in the model (reference temperature $25^{\circ} \mathrm{C}$ )

\begin{tabular}{|c|c|c|c|c|c|}
\hline Parameters (unit) & CB28 & CB101 & CB153 & CB180 & References \\
\hline Molar mass $\left(\mathrm{g} \mathrm{mol}^{-1}\right)$ & 257.5 & 326.4 & 360.9 & 395.3 & $\begin{array}{l}\text { Mackay et al. } \\
\text { (2006) }\end{array}$ \\
\hline Molar volume: $V_{\mathrm{M}}\left(\mathrm{cm}^{3} \mathrm{~mol}^{-1}\right)$ & 247.3 & 289.1 & 310.0 & 330.9 & $\begin{array}{l}\text { Mackay et al. } \\
\text { (2006) }\end{array}$ \\
\hline Henry's law constant $\left(\mathrm{Pa} \mathrm{m}^{3} \mathrm{~mol}^{-1}\right)$ & 31 & 27 & 23 & 22 & $\begin{array}{l}\text { Mackay et al. } \\
\text { (2006) }\end{array}$ \\
\hline Melting point $\left({ }^{\circ} \mathrm{C}\right)$ & 57 & 77 & 103 & 110 & $\begin{array}{l}\text { Mackay et al. } \\
\text { (2006) }\end{array}$ \\
\hline Aqueous solubility $\left(\mathrm{g} \mathrm{m}^{-3}\right)$ & 0.16 & 0.01 & 0.001 & 0.0002 & $\begin{array}{l}\text { Mackay et al. } \\
\text { (2006) }\end{array}$ \\
\hline Vapor pressure $(\mathrm{Pa})$ & 0.034 & 0.0033 & 0.00067 & 0.00013 & $\begin{array}{l}\text { Mackay et al. } \\
\text { (2006) }\end{array}$ \\
\hline $\begin{array}{l}\text { Organic carbon-water partition coefficient Log } \\
\text { Koc (dimensionless) }\end{array}$ & 4.28 & 5.99 & 6.53 & 6.97 & $\begin{array}{l}\text { Mackay et al. } \\
\text { (2006) }\end{array}$ \\
\hline $\begin{array}{l}\text { Octanol-water partition coefficient } \log K_{\mathrm{ow}} \\
\text { (dimensionless) }\end{array}$ & 5.67 & 6.37 & 6.88 & 7.20 & $\begin{array}{l}\text { Mackay et al. } \\
\text { (2006) }\end{array}$ \\
\hline Degradation rate in air: $K_{\mathrm{a}}\left(\mathrm{h}^{-1}\right)$ & $3.50 \times 10^{-7}$ & $4.08 \times 10^{-4}$ & $1.26 \times 10^{-4}$ & $3.50 \times 10^{-8}$ & $\begin{array}{l}\text { Wania et al. } \\
\text { (1999) }\end{array}$ \\
\hline Degradation rate in water: $K_{\mathrm{rw}}\left(\mathrm{h}^{-1}\right)$ & $4.07 \times 10^{-5}$ & $1.26 \times 10^{-5}$ & $1.26 \times 10^{-5}$ & $1.26 \times 10^{-5}$ & $\begin{array}{l}\text { Mackay, et al. } \\
\text { (1992) }\end{array}$ \\
\hline Degradation rate in sediment: $K_{\mathrm{rse}}\left(\mathrm{h}^{-1}\right)$ & $1.26 \times 10^{-5}$ & $1.26 \times 10^{-5}$ & $1.26 \times 10^{-5}$ & $1.26 \times 10^{-5}$ & $\begin{array}{l}\text { Mackay et al. } \\
\text { (1992) }\end{array}$ \\
\hline $\begin{array}{l}\text { Base degradation rate in the six kinds of soil: } K_{\mathrm{s} 0} \\
\left(\mathrm{~h}^{-1}\right)\end{array}$ & $1.26 \mathrm{E} \times 10^{-5}$ & $1.26 \times 10^{-5}$ & $1.26 \times 10^{-5}$ & $1.26 \times 10^{-5}$ & $\begin{array}{l}\text { Mackay et al. } \\
\text { (1992) }\end{array}$ \\
\hline Activation energy of deg. by $\mathrm{OH}$ radicals $\left(\mathrm{J} \mathrm{mol}^{-1}\right)$ & 8314 & 8314 & 8314 & 8314 & $\begin{array}{l}\text { Wania et al. } \\
\text { (1999) }\end{array}$ \\
\hline $\begin{array}{l}\text { Activation energy for freshwater/seawater } \\
(\mathrm{J} \mathrm{mol}\end{array}$ & 30000 & 30,000 & 30,000 & 30,000 & $\begin{array}{l}\text { Beyer et al. } \\
(2002)\end{array}$ \\
\hline Activation energy for air $\left(\mathrm{J} \mathrm{mol}^{-1}\right)$ & 13,700 & 15,000 & 15,400 & 17,800 & $\begin{array}{l}\text { Beyer et al. } \\
(2002)\end{array}$ \\
\hline Activation energy for soil $\left(\mathrm{J} \mathrm{mol}{ }^{-1}\right)$ & 30,000 & 30,000 & 30,000 & 30,000 & $\begin{array}{l}\text { Beyer et al. } \\
\text { (2002) }\end{array}$ \\
\hline
\end{tabular}

study, we introduce the concept of atmospheric transport time (ATT) to interpret the propensity (on a national scale) of chemicals to travel and to explore the influence of prevailing wind in winter and summer on the source-sink relationships and spatial distributions of volatile organic pollutants. The ATT was calculated using ChnGIPERM with single-source emissions of chemical starting on 1 January (wintertime) and 1 July (summertime), respectively. The ATT is derived as simply the estimated time taken (days) for the emitted pollutant to reach the receptor.

Figure 2a depicts the ATT in winter from the emission source (S1) to each receptor, R1, R2, R3, and $\mathrm{R} 4$, which was $20,21,46$, and 66 days from the south (low latitude) to north (high latitude), respectively. In contrast, the ATT was 46, 22, 17, and 21 days in the summer from the low latitude (R1) to high latitude (R4), respectively (Fig. 2b). Some studies have reported that the Westerlies and East Asian monsoons are key factors that can influence the transport patterns of volatile organic pollutants in China (Zhang et al. 2011), and our results add further evidence to corroborate this. The Hadley Cell and Ferrel Cell dominate in different seasons; both move northward in the summer and southward in the winter (Zeng et al. 2011). These atmospheric cycles explain why trans-Pacific transport of pollutants from Asia to the western seaboard of North America is always accompanied by strong westerly winds that are most dominant during winter (Bey et al. 2001; Liu et al. 2003; Zhang et al. 2008). Tian et al. (2009) showed that The East Asian summer monsoons provide the main atmospheric pathways and 

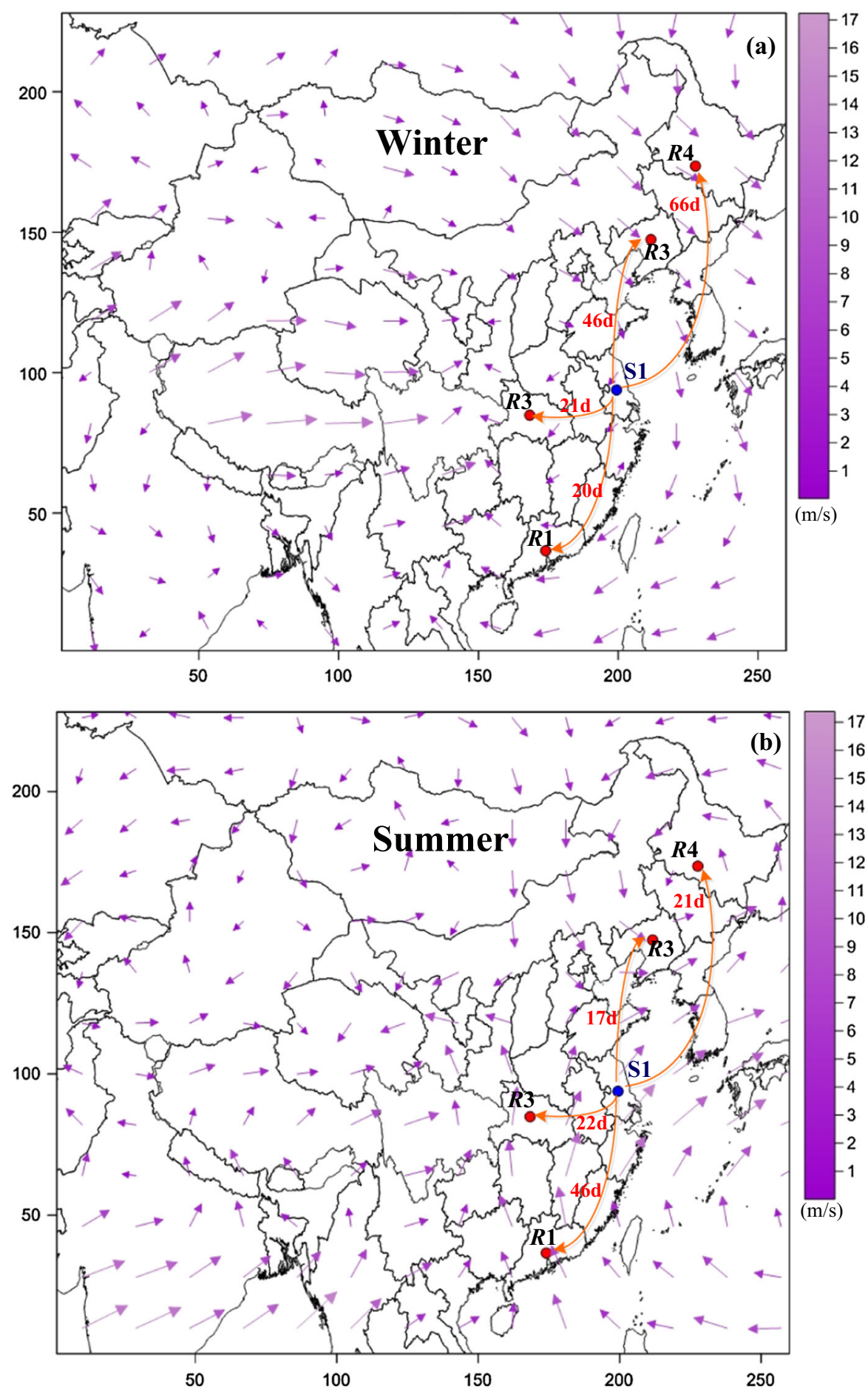

Fig. 2 Atmospheric transport time from the source to receptors in winter (a) and summer (b) for CB28 
summer outflows of $\alpha$-hexachlorocyclohexane $(\alpha-$ $\mathrm{HCH}$ ) over East Asia.

Gas/particle partitioning of PCBs

Atmospheric transport is the main pathway by which most POPs move from source emissions to more remote regions. The environmental fate of POPs is primarily governed by their partitioning between gases and particles (Lohmann et al. 2000). The gasparticle partitioning of chemicals depends on ambient temperature, the nature of ambient aerosols, and the sorption and desorption behaviors of the chemical and aerosol (Pankow and Bidleman 1991; Pankow 1994). The tendency of chemicals to evaporate into the atmosphere is primarily controlled by their vapor pressure (Mackay 2001). Among the congeners included in this study, the most volatile (CB28) has a vapor pressure 4 orders of magnitude higher than the least volatile conger studied (CB180); $-50{ }^{\circ} \mathrm{C} c f$. $50{ }^{\circ} \mathrm{C}$ (Falconer and Bidleman 1994). The subcooled liquid vapor pressure has been used to describe both
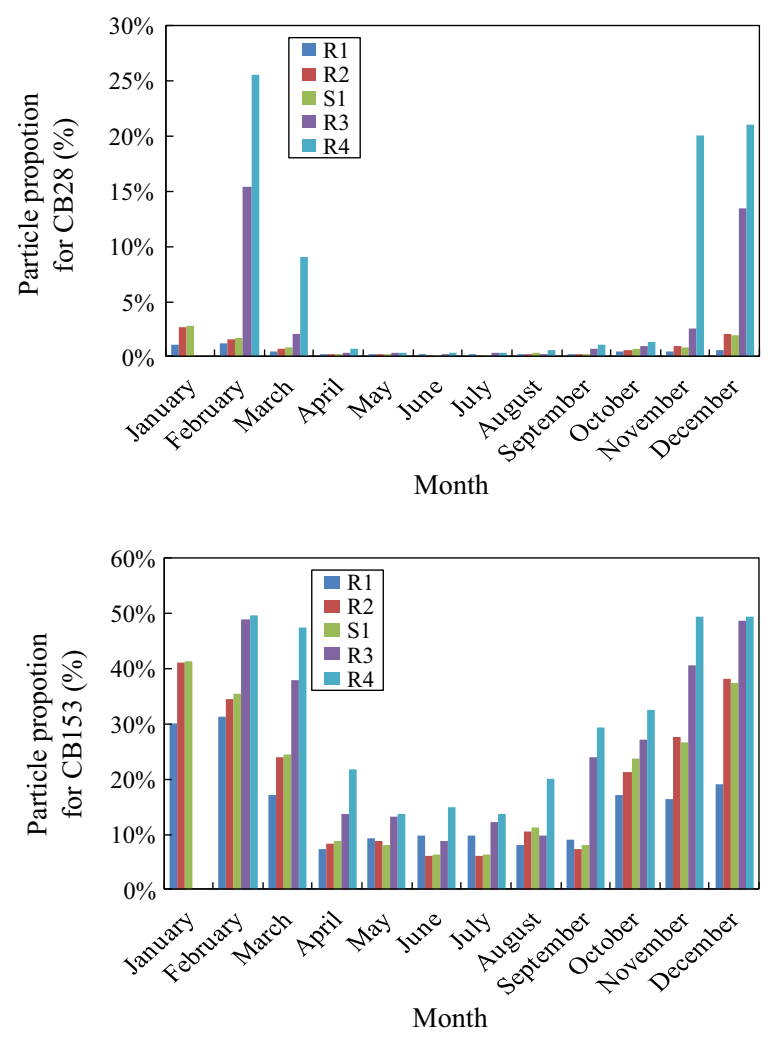

absorptive and adsorptive partitioning (Pankow and Bidleman 1991). If an aerosol contains organic matter, absorptive partitioning will be the dominant mechanism. Absorptive partitioning has been successfully described using the octanol-air partition coefficient $\left(K_{\mathrm{OA}}\right)$ and organic matter content (Harner and Bidleman 1998).

Figure 3 shows that the proportion of each congener sorbed to particles increases with increasing latitude, and the amount of chlorine increases. In winter, this relative increase in particle association is seen for all PCB congeners studied (due to the relatively low temperatures). A reverse trend is observed in the summer for all PCB congeners due to the relatively high temperatures. This effect is especially pronounced for the more volatile congeners; for example, the difference in particle-associated CB28 between R1 and R4 was 20\% in December. During the summer, the presence of the more volatile congeners in the atmosphere is dominated by the gas fraction. All these factors are related to temperature, and the gaseous form can facilitate longer distance transport compared to the
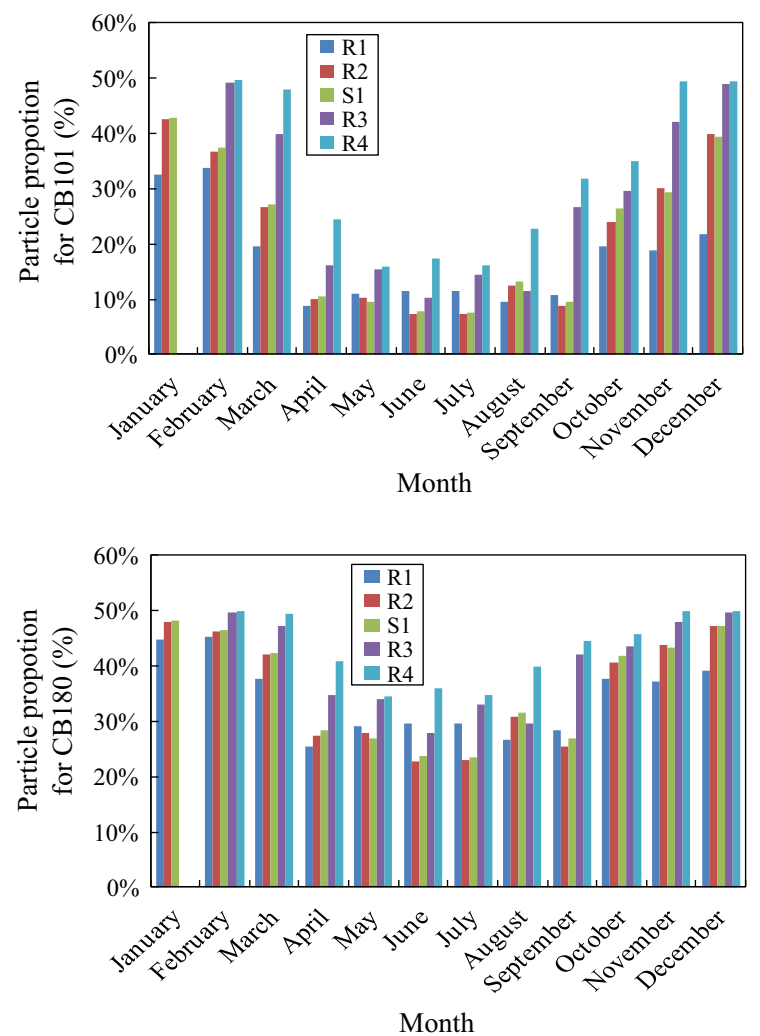

Fig. 3 The particle proportions from low to high latitudes for PCB congeners 

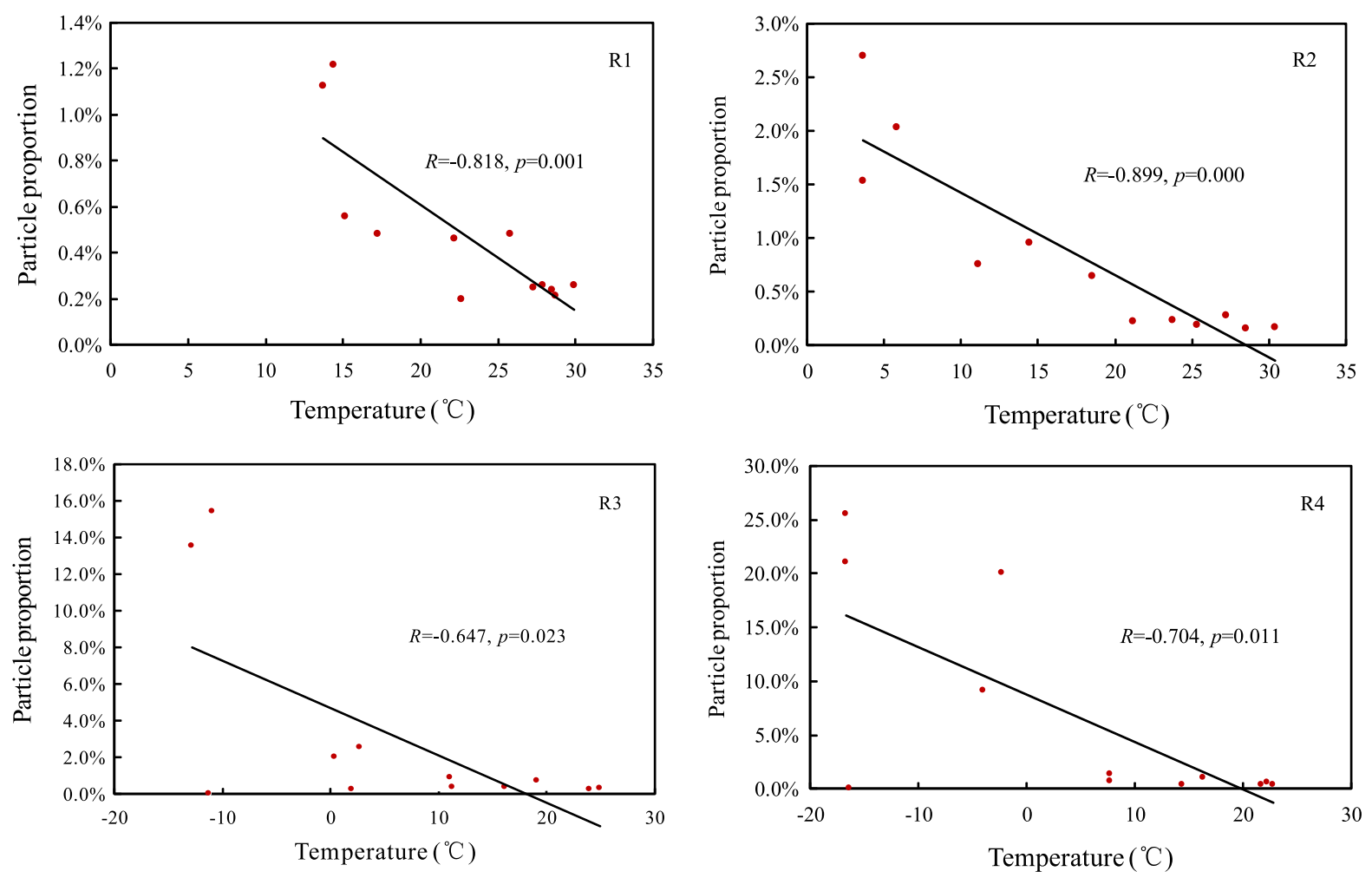

Fig. 4 The relationship between the temperature and particle proportion of CB28 at different receptors

particulate form, which is an important reason for the relatively large differences in the ATT between winter and summer for the farthest receptors. For the lower volatility PCB congeners, the transport capacity is relatively low as their fractionation is more heavily dominated by the particulate form, this effect is particularly pronounced for CB180. A significant negative relationship was elucidated between ambient temperature and the proportion of total atmospheric CB28 present in particulate form at each receptor (Fig. 4).

Primary fractionation effect

\section{The primary fractionation effect for individual $P C B$ congeners}

To better understand primary fractionation, a latitude transecting line (from grid cell 60 to 100) along the emission source was selected to investigate this phenomenon within the ChnGIPERM platform. Figure 5 shows that the highest concentrations for all PCB congeners in soils developed close to the emission source (S1), with gradients of declining concentration with distance from source. These spatial patterns represent the general characteristics of primary fractionation. Within this general distribution pattern, LMW congeners tended to be transported further compared to HMW congeners simply because LMW congeners are easier to transport and undergo relatively more $\mathrm{OH}$ radical reactions in the atmosphere and volatilization (Totten et al. 2002).

The decline in predicted concentrations of each PCB congener in soils north of S1 (grid cells 90 to 100) was steeper than the same estimates for locations south of S1 (grid cells 90 to 60) due to how the January emission period is simulated in ChnGIPERM; the Asia winter monsoon is the prevailing wind. Similarly, concentrations of the HMW congeners tended to be elevated with respect to LMW congeners in soils north of S1, while this pattern was reversed in soils south of $\mathrm{S} 1$ at around grid cell 75 . This pattern may indicate the existence of other primary fractionation characteristics, especially for a set of congeners, indicating that LMW CB28 can be transported farther than HMW CB180. 
Fig. 5 Primary fractionation of individual PCB congeners in January

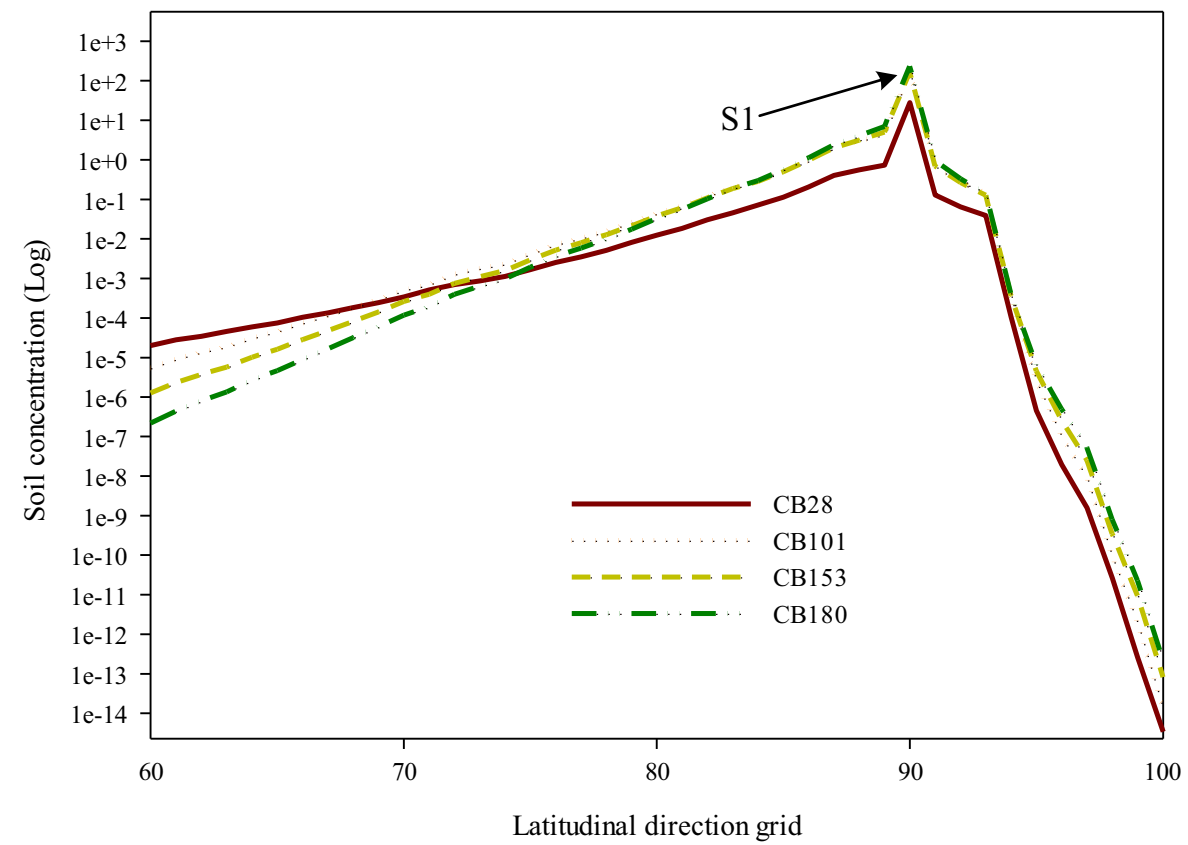

The primary fractionation effect for a set of $P C B$ congeners

Another significant characteristic of primary fractionation is that the ratio of LMW PCB increases with distance. Therefore, the CB28, CB101, CB153, and CB180 were selected as modeled congeners to reveal the fractionation effect, and it can be expressed as follows:

$P_{i}=\frac{C_{i}}{\sum_{i=1}^{n} C_{i}}$

where $P_{i}$ is the ratio fraction, $C_{i}$ is the soil concentration of the individual PCB congener $\left(\mathrm{ng} \mathrm{g}^{-1}\right), i$ is the modeled PCB congener, and $n$ is the number of modeled PCB congeners. In this study, the ratio fraction considered was between CB28 and the total modeled PCB congeners.

In general, more volatile compounds can more easily travel father to remote regions; in contrast, nonvolatile and immobile substances, such as HMW PCBs, tend to remain in their emission region due to rapid deposition (Wania and Mackay 1993). Figure 6 depicts another primary fractionation characteristic: The CB28 proportion is smaller closer to the emission area than other regions, and the CB28 proportion increases with the distance from the emission area.
Secondary fractionation effect

Given that PCBs have been widely banned under the auspices of the Stockholm Convention, secondary emissions are likely to play an important role in their environmental distribution. After entering the environment, POPs often exchange between environmental media such as soil and air as part of a general propensity to move from warmer to colder regions of the globe, a process often referred to as "grasshopping." Alternatively, this process can be termed "secondary fractionation" (Li et al. 2010), whereby chemical transport is primarily driven by temperature, SOM, and surface-air partition coefficients of various environmental media or climate zones. In general, POPs participate in several cycles of deposition and re-emission before reaching their final destinations (Wania and Mackay 1996). The status of POPs in soil and air is mainly controlled by air-soil exchange (Jones 1994). POPs continuously exchange through recycling between the atmosphere and terrestrial environments over long periods of time before they reach equilibrium (Backe et al. 2004). The flux and direction of the air-soil exchange of POPs vary with time and are influenced by climatic factors, soil properties, and chemical emissions (Backe et al. 2004; Cabrerizo et al. 2011; Wang et al. 2012). 
Fig. 6 The fraction of modeled CB28 concentration to the sum of modeled concentrations of all selected congeners in the soil

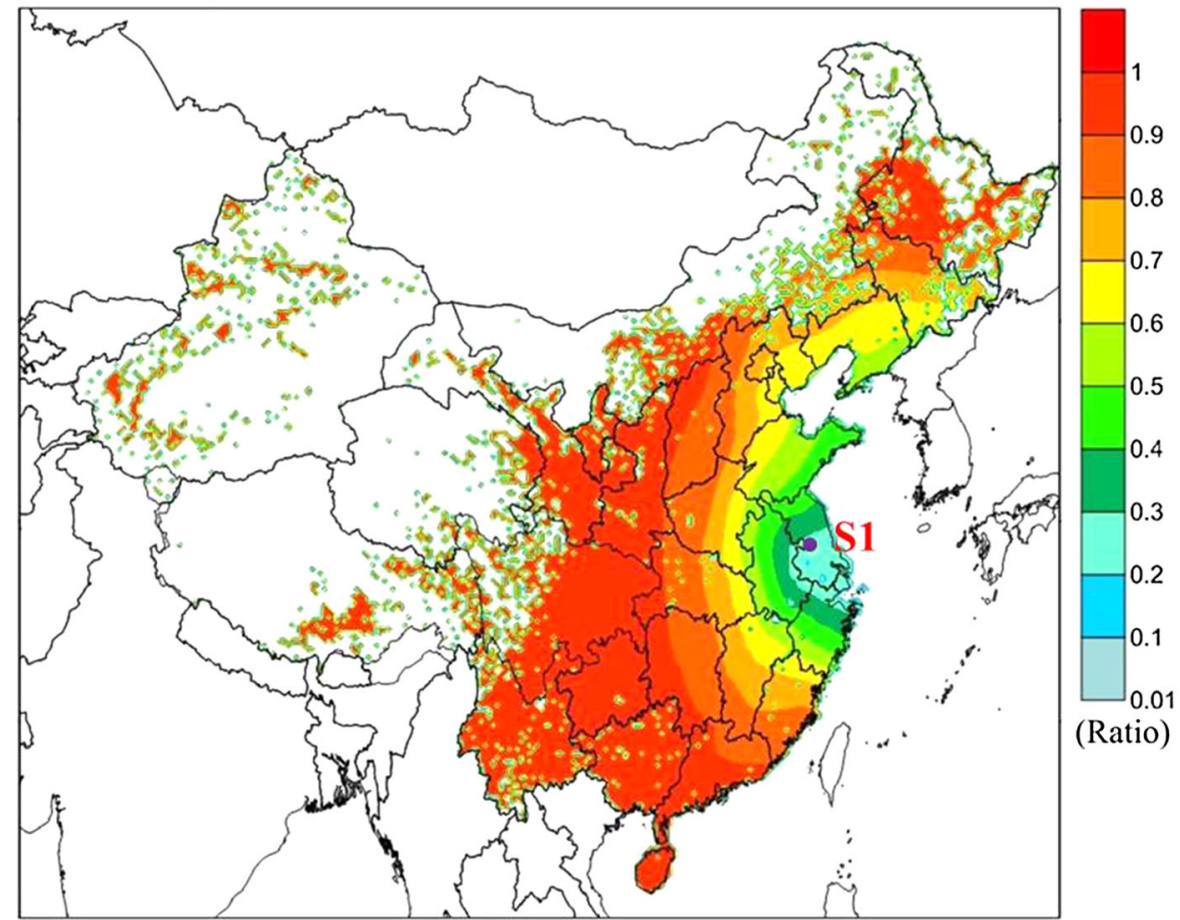

To explore how ChnGIPERM models secondary fractionation effects, the three grid sites F1 $(206,131)$, F2 $(236,151)$, and F3 $(255,178)$ were selected over the whole model domain (Fig. 1). Within these grid cells, data for CB28 indicated that primary fractionation occurred in the emission period in 1965, and subsequently, an irregular trend was observed among the three sites (Fig. 7). Over 20 years after emissions stopped, the CB28 appeared again at the end of the 1980s with an inverse trend from F1 to F3. This phenomenon indicated that ChnGIPERM is able to model secondary fractionation as long-term accumulation in relatively cold climates, but that secondary fractionation is a relatively slow process for CB28 or other relatively volatile POPs. In reality, secondary fractionation can be thought of as a continuous process of multiple deposition/volatilization steps before a chemical reaches its final destination.

To further explore evidence of secondary fractionation within the ChnGIPERM model environment, the SOC, annual average temperature, and soil density were extracted from the environmental and soil property data of the model (Table 2). Soil density is almost the same at the three observation sites (F1, F2, $\mathrm{F} 3$ ), and thus this parameter has limited influence the concentrations of CB28 at the three sites. However, sites $\mathrm{F} 1$ and $\mathrm{F} 2$ have a relatively large difference in temperature, but only a $1 \%$ organic carbon content difference between the sites. The vapor pressures of many POPs increase three- to fourfold for each $10{ }^{\circ} \mathrm{C}$ increase in temperature (Spencer and Cliath 1983), and thus, the volatilization of CB28 has stronger at F1 than F2 and F3. With the same annual average temperature, $\mathrm{F} 3$ has a stronger soil absorption capacity for CB28 than F2 because the SOC content can strongly affect its environmental distribution and reemission from soil. Thus, within ChnGIPERM, both temperature and SOC content play a crucial role in the secondary fractionation of volatile organic pollutants over long-term evolution. However, the secondary fractionation related to soil-air exchange of volatile organic pollutants which is mainly subjected to the temperature and SOC. Cousins et al. (1999) also identified that the temperature and SOC can influence the soil-air exchange of chemicals through calculated soil-air fugacity quotients for selected semivolatile organic compounds (SVOC) in the UK. 


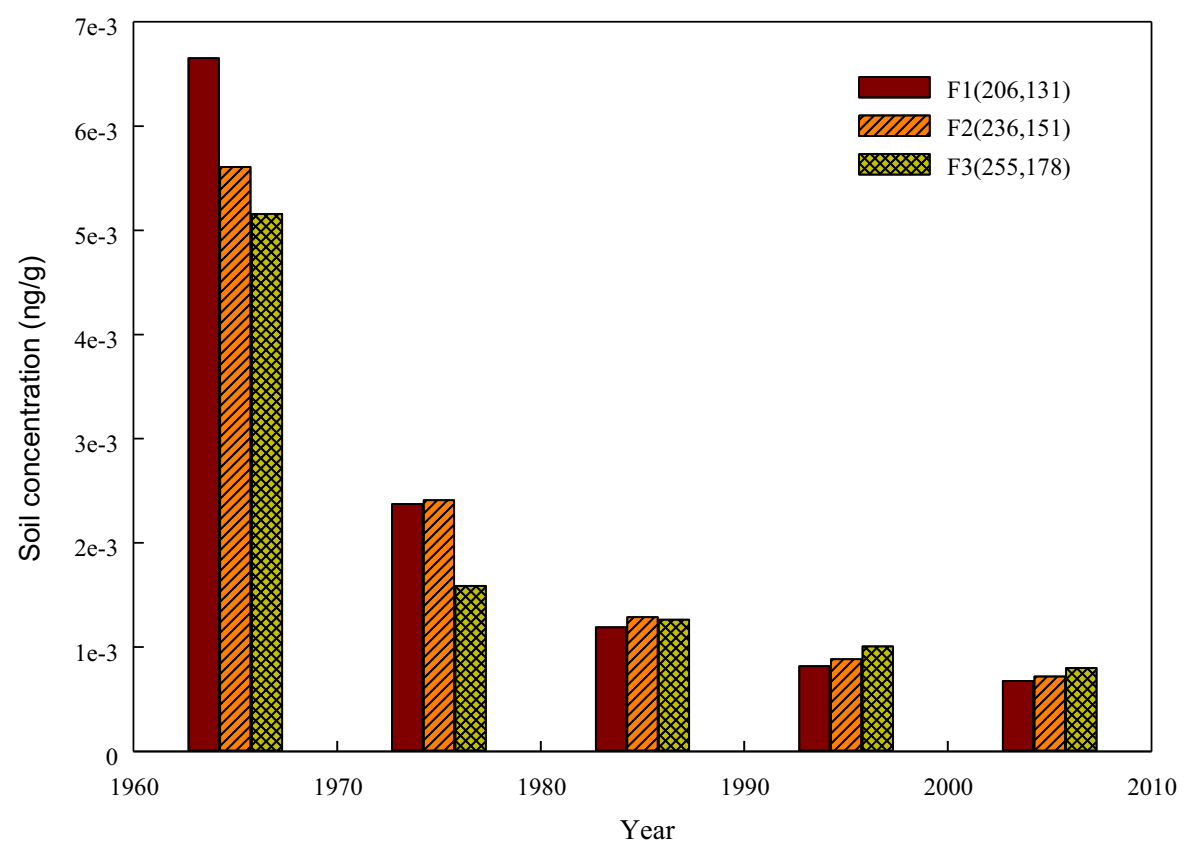

Fig. 7 Variations of CB 28 concentrations in soil over time: evidence of secondary fractionation effect

Table 2 Annual average temperatures and soil properties of the modeled observation sites

\begin{tabular}{llll}
\hline & F1 (206,131) & F2 (236,151) & F3 (255,178) \\
\hline Temperature (K) & 284 & 274 & 275 \\
SOC content (\%) & 2.55 & 1.56 & 8.89 \\
Soil density $\left(\mathrm{kg} \mathrm{m}^{-3}\right)$ & 1345.2 & 1373.9 & 1353.5 \\
\hline
\end{tabular}

\section{Conclusion}

Using ChnGIPERM with single-source emissions, a modeling investigation was carried out to explore the environmental behavior and distribution of PCB congeners modeled over a 46 -year time series. This study showed that atmospheric transport is influenced by meteorological factors, such as Westerlies and East Asia monsoons, and introduced the concept of ATT, which appears promising for describing this phenomenon. The partitioning of PCB congeners between gas and particle forms was mainly controlled by temperature, which can further affect the ATT. In this study, we confirmed that ChnGIPERM adequately models both primary and secondary fractionation effect from single-source PCB emissions, with results in line with our mechanistic understanding.
ChnGIPERM represents secondary fractionation processes of PCBs as slow multiple steps in the environment. This has implications for environmental management and remediation of POPs, given the significant legacy of even those substances which have been banned for many decades.

Acknowledgements This work was supported by the National Natural Science Foundation of China (No. 51779047), the University Nursing Program for Young Scholars with Creative Talents in Heilongiiang Province (UNPYSCT-2016001), and the Startup Foundation of Heilongjiang Postdoctoral Fellows (LBH-Q17010). Valuable comments from anonymous reviewers and editor are highly appreciated.

\section{Compliance with ethical standards}

Conflict of interest The authors declare that they have no competing interests. 


\section{References}

Backe, C., Cousins, I. T., \& Larsson, P. (2004). PCB in soils and estimated soil-air exchange fluxes of selected PCB congeners in the south of Sweden. Environmental Pollution, 128(1-2), 59-72.

Bennett, D. H., McKone, T. E., Matthies, M., \& Kastenberg, W. E. (1998). General formulation of characteristic travel distance for semivolatile organic chemicals in a multimedia environment. Environmental Science and Technology, 32(24), 4023-4030.

Bey, I., Jacob, D. J., Logan, J. A., \& Yantosca, R. M. (2001). Asian chemical outflow to the pacific: Origins, pathways, and budgets. Journal of Geophysical Research, 106, 23097-23114.

Beyer, A., Mackay, D., Matthies, M., Wania, F., \& Webster, E. (2000). Assessing long-range transport potential of persistent organic pollutants. Environmental Science and Technology, 34(4), 699-703.

Beyer, A., Wania, F., Gouin, T., Mackay, D., \& Matthies, M. (2002). Selecting internally consistent physicochemical properties of organic compounds. Environmental Toxicology and Chemistry, 21(5), 941-953.

Bozlaker, A., Odabasi, M., \& Muezzinoglu, A. (2008). Dry deposition and soil-air gas exchange of polychlorinated biphenyls (PCBs) in an industrial area. Environmental Pollution, 156(3), 784-793.

Cabrerizo, A., Dachs, J., Moeckel, C., Ojeda, M. J., Caballero, G., Barceló, D., et al. (2011). Factors influencing the soil-air partitioning and the strength of soils as a secondary source of polychlorinated biphenyls to the atmosphere. Environmental Science and Technology, 45(11), 4785-4792.

Cappelletti, N., Astoviza, M., Morrone, M., \& Tatone, L. (2018). Urban geochemistry and potential human health risks in the Metropolitan Area of Buenos Aires: PAHs and PCBs in soil, street dust, and bulk deposition. Environmental Geochemistry and Health. https://doi.org/10.1007/ s10653-018-0163-3.

Cousins, I. T., Beck, A. J., \& Jones, K. C. (1999). A review of the processes involved in the exchange of semi-volatile organic compounds (SVOC) across the air-soil interface. Science of the Total Environment, 228(1), 5-24.

Coxon, T., Goldstein, L., \& Odhiambo, B. K. (2018). Analysis of spatial distribution of trace metals, $\mathrm{PCB}$, and PAH and their potential impact on human health in Virginian Counties and independent cities, USA. Environmental Geochemistry and Health. https://doi.org/10.1007/s10653-018-0172-2.

Cui, S., Fu, Q., Li, Y. F., Ma, J., Tian, C., Liu, L., et al. (2017). Modeling the air-soil exchange, secondary emissions and residues in soil of polychlorinated biphenyls in China. Scientific Reports, 7(1), 221.

Falconer, R. L., \& Bidleman, T. F. (1994). Vapor pressures and predicted particle/gas distributions of polychlorinated biphenyl congeners as functions of temperature and ortho-chlorine substitution. Atmospheric Environment, 28(3), 547-554.

Goldberg, E. (1975). Synthetic organohalides in the sea. Proceedings of the Royal Society of London, Series B: Biological Sciences, 189, 277-289.

Gouin, T., Mackay, D., Jones, K. C., Harner, T., \& Meijer, S. N. (2004). Evidence for the "grasshopper" effect and fractionation during long-range atmospheric transport of organic contaminants. Environmental Pollution, 128(1-2), 139-148.

Hanh, P. T. M., Nghi, D. T., Lan, T. D., Van Quan, N., \& Viet, P. H. (2018). The status and distribution of PCBs along the coast of Vietnam. Environmental Geochemistry and Health. https://doi.org/10.1007/s10653-018-0168-y.

Harner, T., \& Bidleman, T. F. (1998). Octanol-air partition coefficient for describing particle/gas partitioning of aromatic compounds in urban air. Environmental Science and Technology, 32(10), 1494-1502.

Harner, T., Shoeib, M., Diamond, M., Stern, G., \& Rosenberg, B. (2004). Using passive air samplers to assess urban-rural trends for persistent organic pollutants. 1. Polychlorinated biphenyls and organochlorine pesticides. Environmental Science \& Technology, 38(17), 4474-4483.

Jones, K. C. (1994). Observations on long-term air-soil exchange of organic contaminants. Environmental Science and Pollution Research, 1(3), 172.

Kim, L., Jeon, J. W., Son, J. Y., Park, M. K., Kim, C. S., Jeon, H. J., et al. (2017). Monitoring and risk assessment of polychlorinated biphenyls (PCBs) in agricultural soil from two industrialized areas. Environmental Geochemistry and Health, 39(2), 279-291.

Lammel, G., \& Stemmler, I. (2012). Fractionation and current time trends of PCB congeners: Evolvement of distributions 1950-2010 studied using a global atmosphere-ocean general circulation model. Atmospheric Chemistry and Physics, 12(15), 7199-7213.

Li, Y. F., Harner, T., Liu, L., Zhang, Z., Ren, N. Q., Jia, H., et al. (2010). Polychlorinated biphenyls in global air and surface soil: Distributions, air-soil exchange, and fractionation effect. Environmental Science and Technology, 44(8), 2784-2790.

Li, Z., Kong, S., Chen, L., Bai, Z., Ji, Y., Liu, J., et al. (2011). Concentrations, spatial distributions and congener profiles of polychlorinated biphenyls in soils from a coastal cityTianjin, China. Chemosphere, 85(3), 494-501.

Liu, H., Jacob, D. J., Bey, I., Yantosca, R. M., Duncan, B. N., \& Sachse, G. W. (2003). Transport pathways for Asian pollution outflow over Pacific: Interannual and seasonal variations. Journal of Geophysical Research, 108(D20), 8786.

Lohmann, R., Breivik, K., Dachs, J., \& Muir, D. (2007). Global fate of POPs: Current and future research directions. Environmental Pollution, 150(1), 150-165.

Lohmann, R., Harner, T., Thomas, G. O., \& Jones, K. C. (2000). A comparative study of the gas-particle partitioning of PCDD/Fs, PCBs, and PAHs. Environmental Science and Technology, 34(23), 4943-4951.

Mackay, D. (2001). Multimedia environmental models: The fugacity approach. Boca Raton: CRC Press.

Mackay, D., Shiu, W. Y., \& Ma, K. C. (1992). Illustrated handbook of physical-chemical properties and environmental fate for organic chemicals. I.. Chelsea, MI: Lewis Publishers Inc.

Mackay, D., Shiu, W. Y., Ma, K. C., \& Lee, S. C. (2006). Handbook of physical-chemical properties and environmental fate for organic chemicals (2nd ed.). Boca Raton: CRC Press.

Meijer, S. N., Ockenden, W. A., Steinnes, E., Corrigan, B. P., \& Jones, K. C. (2003). Spatial and temporal trends of POPs in 
Norwegian and UK background air: Implications for global cycling. Environmental Science and Technology, 37(3), 454-461.

Meijer, S. N., Steinnes, E., Ockenden, W. A., \& Jones, K. C. (2002). Influence of environmental variables on the spatial distribution of PCBs in Norwegian and UK soils: Implications for global cycling. Environmental Science and Technology, 36(10), 2146-2153.

Motelay-Massei, A., Ollivon, D., Garban, B., Teil, M. J., Blanchard, M., \& Chevreuil, M. (2004). Distribution and spatial trends of PAHs and PCBs in soils in the Seine River basin, France. Chemosphere, 55(4), 555-565.

Pankow, J. F. (1994). An absorption model of gas/particle partitioning of organic compounds in the atmosphere. Atmospheric Environment, 28(2), 185-188.

Pankow, J. F., \& Bidleman, T. F. (1991). Effects of temperature, TSP and per cent non-exchangeable material in determining the gas-particle partitioning of organic compounds. Atmospheric Environment. Part A. General Topics, 25(10), 2241-2249.

Pokhrel, B., Gong, P., Wang, X., Chen, M., Wang, C., \& Gao, S. (2018). Distribution, sources, and air-soil exchange of OCPs, PCBs and PAHs in urban soils of Nepal. Chemosphere, 200, 532-541.

Ren, N. Q., Que, M. X., Li, Y. F., Liu, L. Y., Wang, X. N., Xu, D. D., et al. (2007). Polychlorinated biphenyls in Chinese surface soils. Environmental Science and Technology, 41(11), 3871-3876.

Scheringer, M., Salzmann, M., Stroebe, M., Wegmann, F., Fenner, K., \& Hungerbühler, K. (2004). Long-range transport and global fractionation of POPs: Insights from multimedia modeling studies. Environmental Pollution, 128(1-2), 177-188.

Schuster, J. K., Gioia, R., Moeckel, C., Agarwal, T., Bucheli, T. D., Breivik, K., et al. (2011). Has the burden and distribution of PCBs and PBDEs changed in European background soils between 1998 and 2008? Implications for sources and processes. Environmental Science and Technology, 45(17), 7291-7297.

Spencer, W. F., \& Cliath, M. M. (1983). Measurement of pesticide vapor pressures. In Residue reviews (pp. 57-71). New York, NY: Springer.

Stemmler, I., \& Lammel, G. (2012). Long-term trends of continental-scale PCB patterns studied using a global atmosphere-ocean general circulation model. Environmental Science and Pollution Research, 19(6), 1971-1980.

Sweetman, A. J., Cousins, I. T., Seth, R., Jones, K. C., \& Mackay, D. (2002). A dynamic level IV multimedia environmental model: Application to the fate of polychlorinated biphenyls in the United Kingdom over a 60-year period. Environmental Toxicology and Chemistry, 21(5), 930-940.

Tian, C., Ma, J., Liu, L., Jia, H., Xu, D., \& Li, Y. F. (2009). A modeling assessment of association between East Asian summer monsoon and fate/outflow of $\alpha-\mathrm{HCH}$ in Northeast Asia. Atmospheric Environment, 43(25), 3891-3901.

Totten, L. A., Eisenreich, S. J., \& Brunciak, P. A. (2002). Evidence for destruction of $\mathrm{PCBs}$ by the $\mathrm{OH}$ radical in urban atmospheres. Chemosphere, 47(7), 735-746.

UNEP. (2001). Final Act of the plenipotentiaries on the stockholm convention on persistent organic pollutants (p. 445). Geneva: United Nations Environment Program Chemicals. von Waldow, H., MacLeod, M., Jones, K., Scheringer, M., \& Hungerbühler, K. (2010). Remoteness from emission sources explains the fractionation pattern of polychlorinated biphenyls in the northern hemisphere. Environmental Science and Technology, 44(16), 6183-6188.

Wang, P., Li, Y., Zhang, Q., Yang, Q., Zhang, L., Liu, F., et al. (2017). Three-year monitoring of atmospheric PCBs and PBDEs at the Chinese Great Wall Station, West Antarctica: Levels, chiral signature, environmental behaviors and source implication. Atmospheric Environment, 150, 407-416.

Wang, X. P., Sheng, J. J., Gong, P., Xue, Y. G., Yao, T. D., \& Jones, K. C. (2012). Persistent organic pollutants in the Tibetan surface soil: Spatial distribution, air-soil exchange and implications for global cycling. Environmental Pollution, 170, 145-151.

Wania, F., \& Mackay, D. (1993). Global fractionation and cold condensation of low volatility organochlorine compounds in polar regions. Ambio, 22(1), 10-18.

Wania, F., \& Mackay, D. (1996). Peer reviewed: Tracking the distribution of persistent organic pollutants. Environmental Science and Technology, 30(9), 390A-396A.

Wania, F., Mackay, D., McLachian, M., Sweetman, A., \& Jones, K. (1999). Global modelling of polychlorinated biphenyls. WECC report, $1,99$.

Wegmann, F., Scheringer, M., \& Hungerbühler, K. (2006). First investigations of mountainous cold condensation effects with the CliMoChem model. Ecotoxicology Environmental and Safety, 63(1), 42-51.

Wu, S., Xia, X., Yang, L., \& Liu, H. (2011). Distribution, source and risk assessment of polychlorinated biphenyls (PCBs) in urban soils of Beijing. China. Chemosphere, 82(5), 732-738.

Xing, Y., Lu, Y. L., Dawson, R. W., Shi, Y. J., Zhang, H., Wang, T. Y., et al. (2005). A spatial temporal assessment of pollution from PCBs in China. Chemosphere, 60, 731-739.

Yadav, I. C., Devi, N. L., Li, J., Zhang, G., \& Breivik, K. (2017). Possible emissions of POPs in plain and hilly areas of Nepal: Implications for source apportionment and health risk assessment. Environmental Pollution, 220, 1289-1300.

Zeng, G., Wang, W. C., Sun, Z. B., \& Li, Z. X. (2011). Atmospheric circulation cells associated with anomalous East Asian winter monsoon. Advanced Atmospheric, Science, 28(4), 913-926.

Zhang, L., Ma, J., Venkatesh, S., Li, Y. F., \& Cheung, P. (2008). Modeling evidence of episodic intercontinental long-range transport of lindane. Environmental Science and Technology, 42(23), 8791-8797.

Zhang, Y., Shen, H., Tao, S., \& Ma, J. (2011). Modeling the atmospheric transport and outflow of polycyclic aromatic hydrocarbons emitted from China. Atmospheric Environment, 45(17), 2820-2827.

Zhao, S., Breivik, K., Liu, G., Zheng, M., Jones, K. C., \& Sweetman, A. J. (2017). Long-term temporal trends of polychlorinated biphenyls and their controlling sources in China. Environmental Science and Technology, 51(5), 2838-2845.

Publisher's Note Springer Nature remains neutral with regard to jurisdictional claims in published maps and institutional affiliations. 